\title{
State-of-the-art Charging Solutions for Electric Transportation and Autonomous E-mobility
}

\author{
Siddhartha A. Singh, Deepak Ronanki, A. V. J. S. Praneeth, and Sheldon S. Williamson \\ Smart Transportation Electrification and Energy Research (STEER) Group Advanced Storage Systems and \\ Electric Transportation (ASSET) Laboratory UOIT-Automotive Center of Excellence (UOIT-ACE) Department of \\ Electrical, Computer, and Software Engineering Faculty of Engineering and Applied Science University of \\ Ontario-Institute of Technology ACE-2025, 2000 Simcoe Street North Oshawa, ON L1H 7K4, Canada \\ Tel: +1/(905) 721-8668, ext. 5744 Fax: +1(905) 721-3178 \\ sheldon.williamson@uoit.ca \\ http://www.engineering.uoit.ca/; http://ace.uoit.ca/
}

\begin{abstract}
As regards moving towards electrification of transportation, there is need to replace gas stations with Electric Vehicle (EV) charging stations at equally convenient locations and look at various energy storage methods onboard an electric vehicle. There are various charging methods which have been discussed in the literature. This paper discusses some new charging technology that can possibly have a tremendous impact on the future of energy storage in transportation electrification.
\end{abstract}

Keywords - electrification of transportation; Electric Vehicle; Ev; Electric; Vehicle charging station; energy storage; autonomous electric vehicle.

\section{INTRODUCTION}

Charging of an Electric vehicle can be universally classified into Plug-in Charging Technique and Wireless Charging Technique. Plug-in Charging can be further classified into $A C$ charging and $D C$ charging. Plug-in $A C$ charging is achieved by connecting the $A C$ grid to the onboard battery charging system through a connector. The on-board battery charging system consists of the onboard rectifier, the power factor correction stage and the
DC-DC converter/charger as shown in Fig 1 using a block diagram. [1][2][3]

Fig.2, shows the typical architecture of an off-board Plug-in DC charging station. All the power conversion units are off-board the electric vehicle. The galvanic isolation for safety is achieved either through a bulky $60 \mathrm{~Hz}$ isolation transformer between the AC grid and the rectifier or a High frequency $(\mathrm{HF})$ isolation transformer at the DC-DC conversion stage. DC charging of an EV reduces the need of multiple power conversion units on-board as well as off-board the $\mathrm{EV}$. The battery on-board the electric vehicle is directly charged by the off-board converters. [4][5] The Society of Automobile Engineers (SAE) has included DC level I and level II charging in the J1772 standard [6].

Wireless charging of Electric vehicle batteries can also be classified as an on-board charging technique. The power transfer is achieved by contactless plates, through capacitive power transfer (CPT), or contactless coils or magnetic cores, through Inductive Power Transfer (IPT). The overall structure of the power conversion system remains the same for both IPT and CPT as shown using a block diagram in Fig.2. 


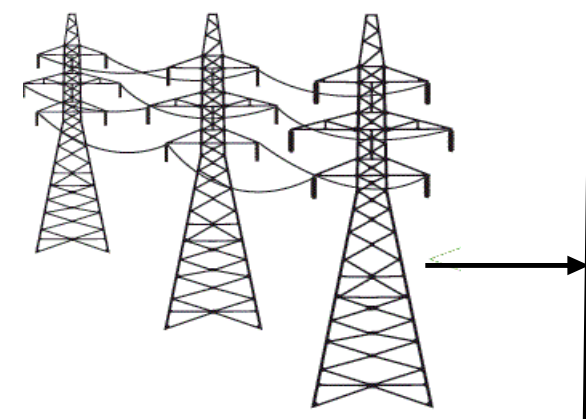

AC Grid

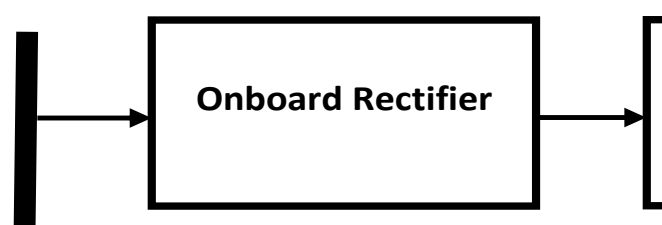

On-board an Electric

Vehicle
Power Factor Correction Stage

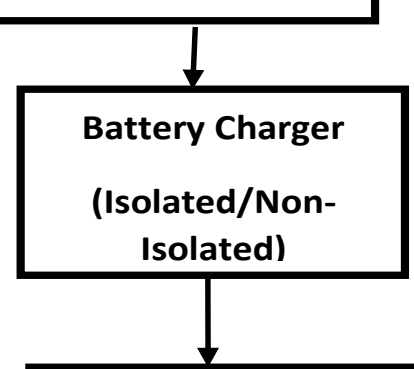

On-board EV Battery

Fig.1. Block diagram of a typical on-board plug-in AC charging architecture

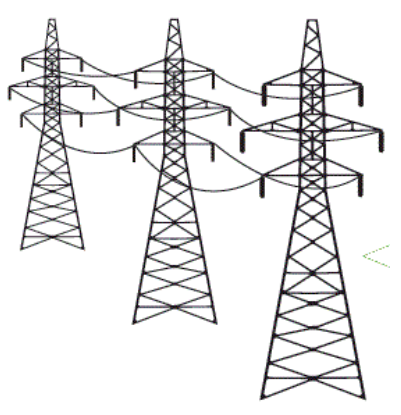

AC Grid

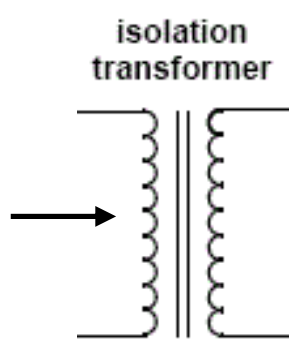

On-board Electric Vehicle

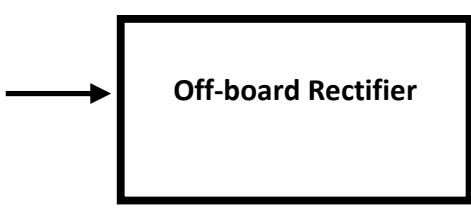

Off-board

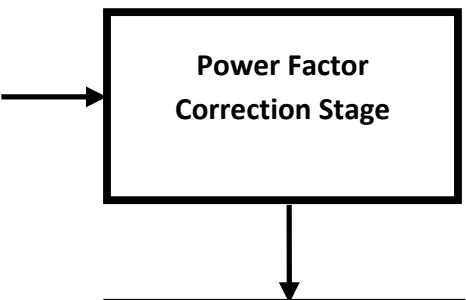

DC-DC Charger

(HF GALVANIC

ISOLATION*)

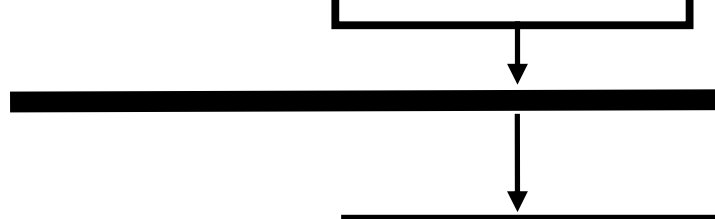

On-board EV Battery

Fig.2. Block diagram of a typical off-board plug-in DC charging architecture 


\section{On-board Electric Vehicle}

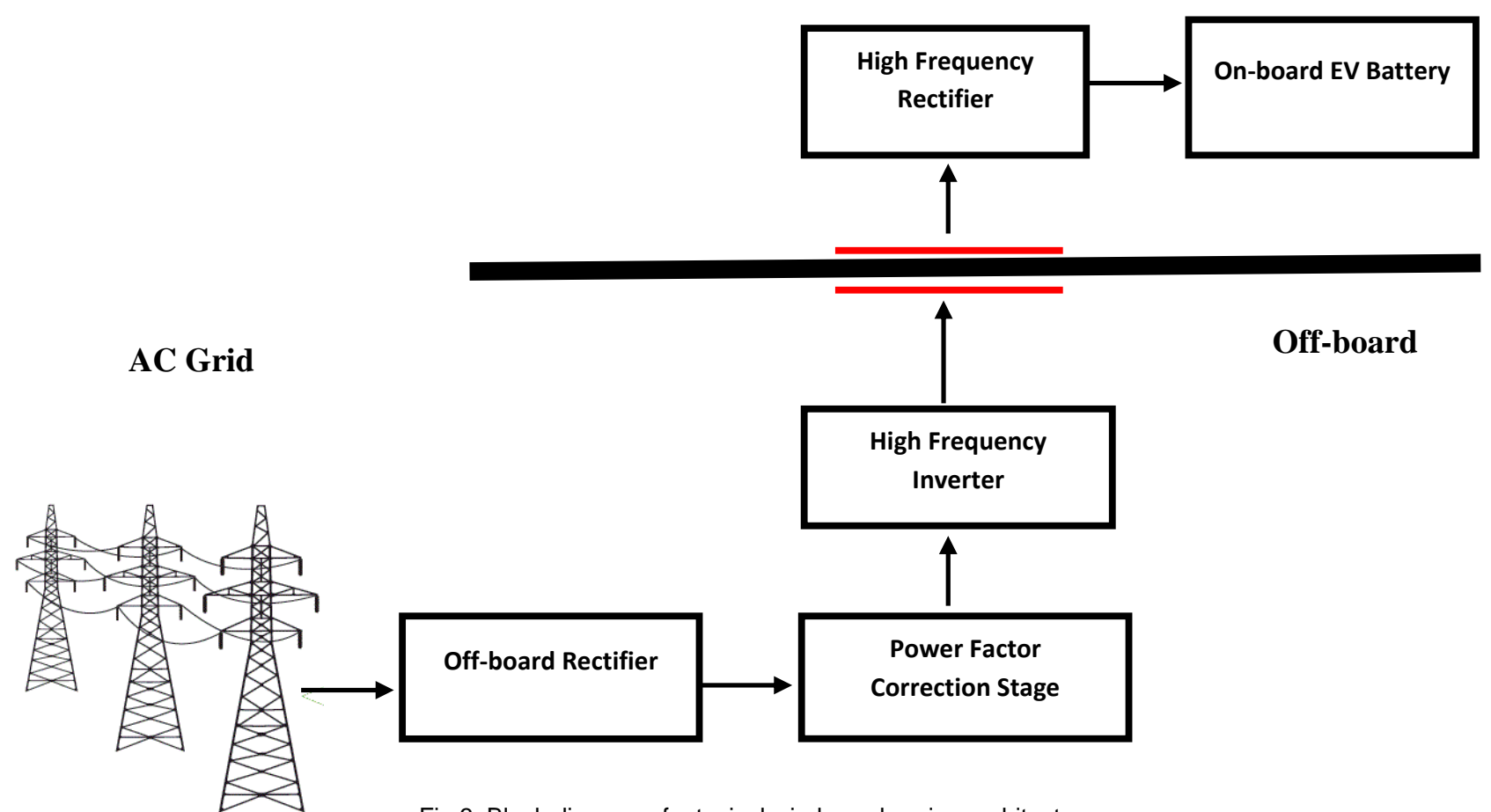

Fig.3. Block diagram of a typical wireless charging architecture

The lines marked in red can either be contactless plates or coils depending on the power transfer technique used. The AC grid provides the entire power required by the EV to charge the battery. The power factor correction stage and the primary of the high frequency transformer is moved off-board. The secondary of the high frequency transformer which is connected to the battery using a rectifier is present on-board the electric vehicle. [6]-[8]

The on-board chargers are with limited power and compact size which are suitable inside a vehicle. On the other hand, for off-board charging eliminates the need for power conversion units on-board the EV. The off-board charging involves redundant power electronic components with bulky size and the associated extra costs for installations. The use of renewable energy for charging of EVs has become a very important area of interest in recent times. During charging of EV using the plug-in off-board technique and even the WPT techniques, there is a huge dependency on the AC grid. Use of multiple power conversion stages contribute to the overall reduction in efficiency.

The use of a renewable energy source interconnected to the AC for energy storage has been used in the past for energy storage systems providing back up power as well as for charging of electric vehicles. As mentioned previously, EV charging systems require multiple stages and the number of stages increases further when interconnecting such charging infrastructure to the AC grid. Usually, residential or semi commercial solar photovoltaic arrays have a lower voltage available at the output of the array and require a boost stage to match the photovoltaic output voltage to the grid connected inverter.

Table 1. DC Charging Electrical Ratings (North America)

\begin{tabular}{|c|c|c|c|}
\hline $\begin{array}{c}\text { Charging } \\
\text { Level }\end{array}$ & $\begin{array}{c}\text { Battery } \\
\text { Voltage Level } \\
\text { (V) }\end{array}$ & $\begin{array}{c}\text { Type of } \\
\text { charger }\end{array}$ & $\begin{array}{c}\text { Max. } \\
\text { Continuous } \\
\text { Current (A) }\end{array}$ \\
\hline Level-I & $200-450 \mathrm{~V}$ & Off-Board & $80 \mathrm{~A}$ \\
\hline Level-II & $200-450 \mathrm{~V}$ & Off-Board & $200 \mathrm{~A}$ \\
\hline $\begin{array}{c}\text { Level III } \\
\text { (proposed) }\end{array}$ & $200-450 \mathrm{~V}$ & Off-Board & $400 \mathrm{~A}$ \\
\hline
\end{tabular}

For future electrified transportation, some of the key areas of interests are the development of technologies which are compact, highly efficient and less dependent on the $\mathrm{AC}$ grid.

In the following sections, new technologies have been discussed which are going to play important 
roles in the electrification of transportation as there is a trend to move towards a greener planet. In section III, a solar-grid interconnected single stage DC charger has been discussed for residential and semicommercial applications providing level I and Level II charge (DC) for EVs, section IV discusses an onboard EV motor drive integrated energy storage system and section $V$, on-board EV charging has been discussed.

\section{SOLAR-GRID INTERCONNECTED SINGLE STAGE DC CHARGING FOR RESIDENTIAL/SEMI-COMMERCIAL OFF- BOARD CHARGING}

Z-source inverters were first proposed in [10]. They have a unique ability to buck or boost in a single stage through two inductors and two capacitors in a ' $X$ ' shaped connection. A modified Z-source inverter (M-ZSI) for DC charging, shown in Fig.4, was first proposed in [11][12]. Each of the impedance network capacitance in split into two capacitors, CHB.

Each of the two capacitors leg acts as a source to split primary isolated half bridge converter. The secondary of the high frequency transformer, $\mathrm{T}$, is connected to the EV battery, for simplicity, using a battery internal resistance, $\mathrm{rB}$ and a battery voltage VB. The switch S5, is used instead of a diode to prevent unwanted turn on and off and maintain a constant current for bidirectional power flow. The diode bridge of the secondary side of the high frequency transformer, $\mathrm{T}$, is replaced by an active bridge for bi-directional power flow operation.

The basic operation of this proposed topology is based on the power balance equation given by,

$P_{\text {charge }}=P_{P V}+P_{\text {Grid }}$

The various modes of operation are PV to GRID, PV+GRID to EV battery and EV battery to GRID. During the PV to Grid mode, the generated photovoltaic power is directly fed into the grid in the absence of an EV connected to the charger. In the $\mathrm{PV}+$ Grid to EV mode, the grid and the PV provide the required power for the battery. Any fluctuation in the PV power is compensated by the grid. The various power-efficiency curves for this topology is shown in figure 5.

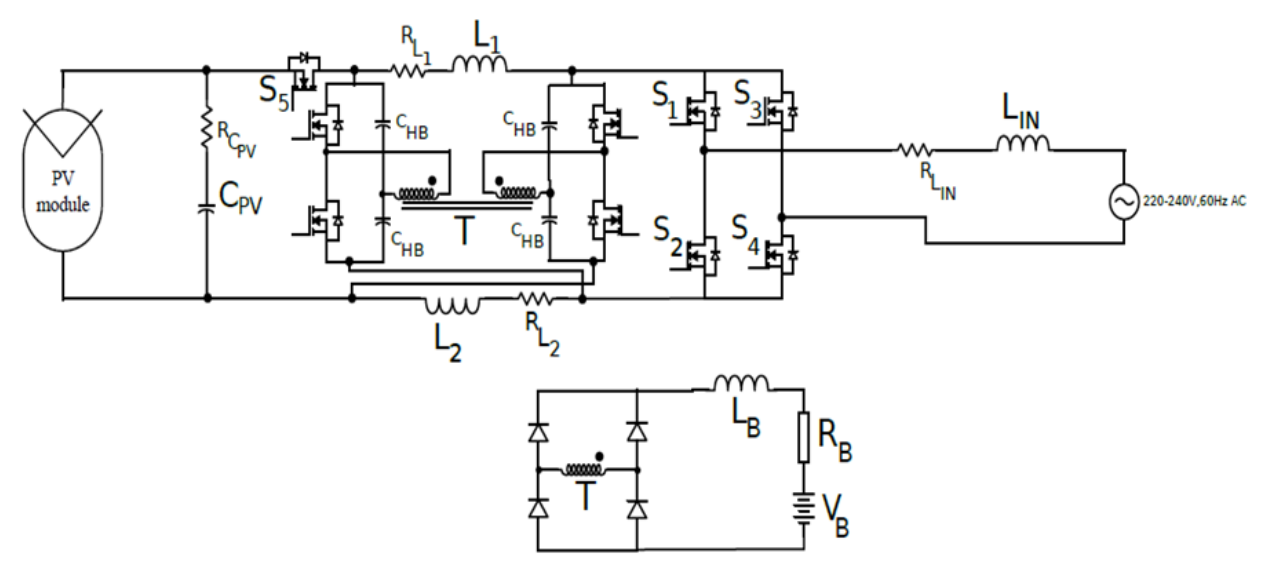

Fig.4. Proposed modified Z source converter based single stage topology

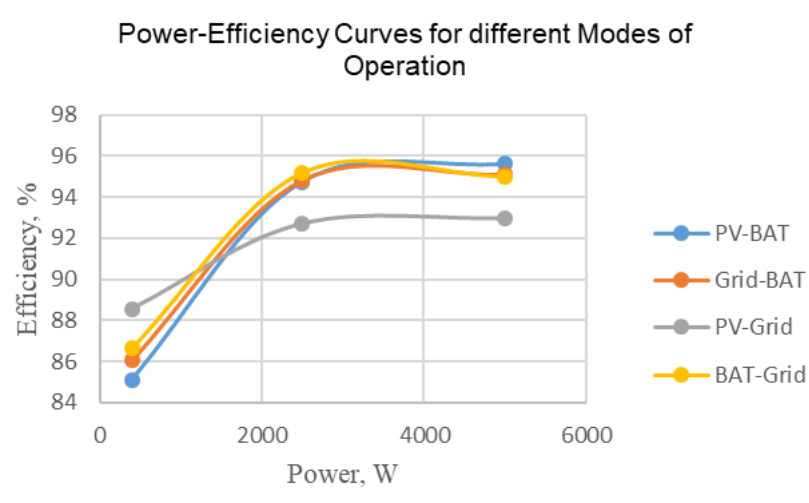

Fig.5. Efficiency curves for different modes of operation for a
From the curves, it can be seen that the efficiency of the PV-BAT is the highest at $95.9 \%$. For Grid to Battery or Battery to Grid (V2G) it is almost the same at $95 \%$. The efficiency from PV to Grid is $93 \%$. The advantages of the proposed topology are: Reliability, lesser number of power stages during different modes of operation. 


\section{INTEGRATED MOTOR DRIVE AND ON-BOARD BATTERY CHARGERS}

The on-board chargers have restriction of power due to their weight, space, cost constraints and isolation requirements [13]. To limit these constraints, integration of charging task in the electric traction system is a feasible solution as these operations are not simultaneous. The basic idea of an integrated charger is usage of motor windings as filter inductors or an isolated transformer and the inverter functions as a bi-directional AC-DC converter and these are considered as the integrated motor drive and battery chargers [14], [15]. This provides a major advantage that levels 2 and 3 have a high power bidirectional charger with unity power factor at low cost [16]. These chargers can be classified based on converter configuration, motor type and construction, number of motor phases and type of wheel drive. An integrated motor drive and battery charger system were commercially used in electric cars by AC Propulsion Inc. [17] based on an induction machine and General Motors Inc. [18], Ford company [19], Valeo Engine and Electrical Systems [20] use split winding AC motor topology without switch like a contactor [21]. These integrated chargers are already used in two wheelers [22], fork lift trucks [23] and cars [24]. A few advancements in motor topology modifications in order to operate as a three phase PFC coupled boost rectifier are split-phase induction motor [25], special double winding machine [26], split-phase permanent magnet synchronous motor [27], split-phase permanent magnet assisted synchronous reluctance motor [28], delta-star permanent magnet synchronous motor [29], split-phase switched reluctance motor [30] and multiphase machines [31], [32]. Few examples of using topologies without. without motor modifications are in four-wheel drive system [33] and integrated charger with switched reluctance motor (SRM) drive presented in [34] uses embedded components of motor and converters with voltage boosting feature and PFC charging and [35] multilevel converter fed SRM.

In this section, main focus is on Modular Multilevel Converter (MMC) which serves as an integrated converter for onboard fast charger and motor drive system. The MMC offers advantages such as modular realization, inherent redundancy, low total harmonic distortion, higher efficiency with standard devices, filter less configuration, no capacitors at DC bus, no filters at $A C$ and $D C$ side which are made to use in EVs [36], [37]. MMC can be realized as a i) power converter driving the motor ii) effective battery management system by submodule control iii) AC charging through arm inductances with sequence of operation of submodules. In addition, MMC provides fault tolerant capability, redundancy of modules and elimination of large DC link capacitors.

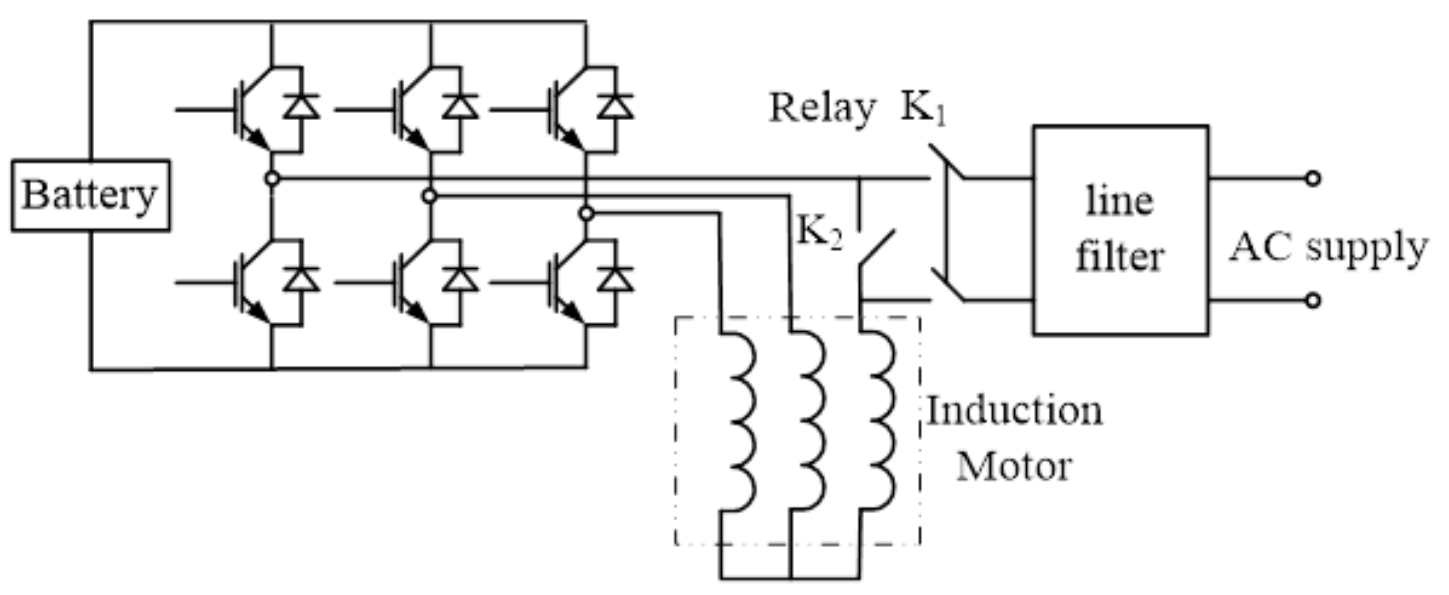

Fig.6. Schematic of a 3 phase motor drive. 


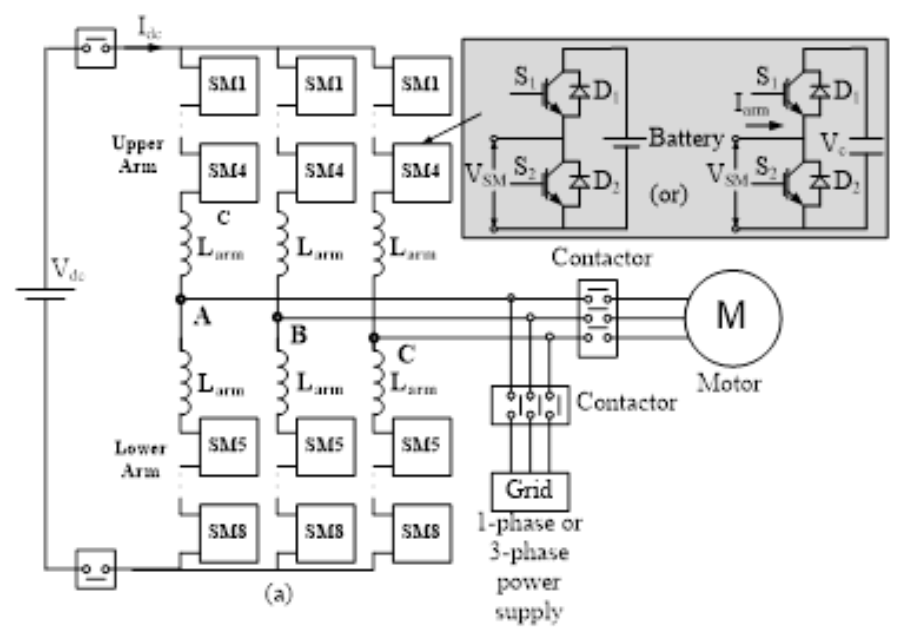

Fig.7. Schematic of a MMC based motor drive

However, these are associated with some problems and can be summarized as [38]-[41]: i) It requires a higher number of semiconductors, gate drivers and corresponding control equipment. ii) Energy stored in distributed capacitors is considerably higher than conventional inverters. iii) It also requires a higher number of sensors to monitor capacitor voltages and arm currents. The major issue with MMC is that it requires a capacitor balancing algorithm and circulating current suppression control as it contains a double frequency component, which increases the stress and losses in power switching devices [40], [41]. MMC with the use of wide gap power switching devices can be a future solution for integrated fast on board charger and motor drive system in autonomous vehicles with features of high reliability, efficiency and redundancy. This makes the easy and identical modules manufacturing, hierarchical redundancy capability and reduction in dimensions of the whole converter for automotive manufacturers at the cost of improved technology at submodule.

\section{ONBOARD-CHARGING}

In all the autonomous and self-driven electric vehicles, energy in the battery can be refilled with battery chargers which must be highly efficient and reliable, with high power density, low cost, and low volume and weight. The charging time and battery life are linked to the characteristics of the battery charger. The most important criteria in selection of on-board battery charger for a vehicle is based on the available battery pack ratings (kWh) and limited weight to space ratio to maintain average charging time to a low value.

The power flow from the battery chargers can be unidirectional or bidirectional. In Unidirectional charging the power flow is from grid to the vehicle. So it limits hardware requirements and simplifies interconnection issues. In a bidirectional charging it allows charging from the grid and battery energy injection back to the grid (vehicle to grid).

Table 2. AC Charging Electrical Ratings (North America)

\begin{tabular}{|c|c|c|c|c|c|}
\hline Charging Level & Voltage Level & Type of Charger & Interface Equipment & Power Level & Charging Time \\
\hline Level-I & $\begin{array}{c}120 \mathrm{~V} \text { ac(US) } \\
230 \mathrm{~V} \mathrm{ac}(\mathrm{EU})\end{array}$ & On-Board & Type-I(J1772) & Upto-3.3KW & $6-9 \mathrm{hours}$ \\
\hline Level-II & $\begin{array}{c}240 \mathrm{~V} \mathrm{ac}(\mathrm{US}) \\
400 \mathrm{~V} \text { ac(EU) }\end{array}$ & On-Board & Type-II connector & $7.7-43 \mathrm{KW}$ & $1-4 \mathrm{hours}$ \\
\hline \multirow{2}{*}{ Level-III } & $\begin{array}{c}\text { Single phase and 3 } \\
\text { phase } \\
\text { (proposed) }\end{array}$ & \multicolumn{3}{|c|}{$>20 \mathrm{~kW}$} & \\
\hline
\end{tabular}


This is the latest trend in the charging systems with the automotive (CAR2HOME) to grid. It stabilizes the power with adequate power conversion when it is plugged to grid. The on-board charging through the renewable generations (Solar) helps to minimize the additional power stabilizing equipment in the vehicle. The concept of sun2car shown in Fig: 1 is one of the solutions for charging the vehicle through a PV used by Toyota and Nissan. Fig: 2 shows the Tesla's super charger, which provides a huge research scope in extracting the maximum energy from the sun and utilize it for charging the EV battery pack. There are various topologies involved in onboard charger for charging the electric vehicle [3] [41]. Most of the onboard chargers have the front-end topology as ACDC power conversion to maintain the power quality in the system when the vehicle was connected to a grid supply for charging [42]. The converted DC will normally have a huge low frequency ripple which will affect the life of the battery especially the li-ion battery [43]. There should a two-stage power conversion required in a li-ion battery pack to reduce the low voltage ripple content and to make it easy to implement the charger control algorithms [44]. There are many topologies in PFC like interleaved, bridgeless, semi-bridgeless, which can improve the output ripple in capacitors and the heat management problems in the converter. In this paper, the researchers are interested in reducing the charge time of the vehicle with high power quality. There are different topologies in ac-dc converters with good power quality and less harmonics discussed in [45] [46]. Proper selection of the PFC topology helps to minimize the low frequency ripple, the power quality, and the size of EMI filter and emissions.

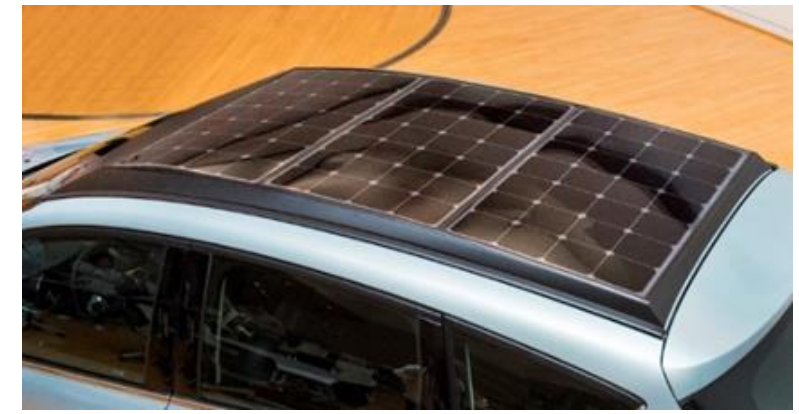

Fig.8 Sun2Car concept

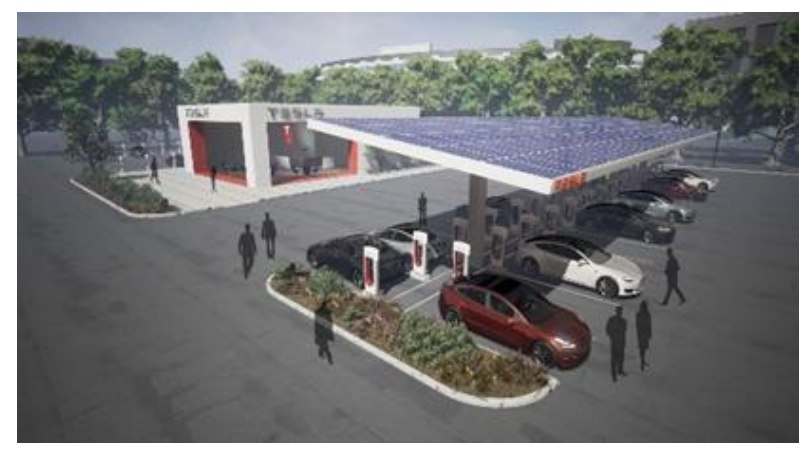

Fig. 9. Tesla Super Charger

To avoid the bulky capacitors at the PFC, [48] provides a solution for sinusoidal charging that can be implemented through using bidirectional converters. There are different stages in the battery charger, represented in the block diagram (Fig. 3). The main motivation is to compact the size of the charger and improve the efficiency at full load conditions. There are many contributions to improve the efficiency of the converters [45]-[47]. The resonant converters at the $D C / D C$ side have the major role in deciding the efficiency of the whole charger with isolation transformer and wide control algorithms implementations for charging the battery packs [49].

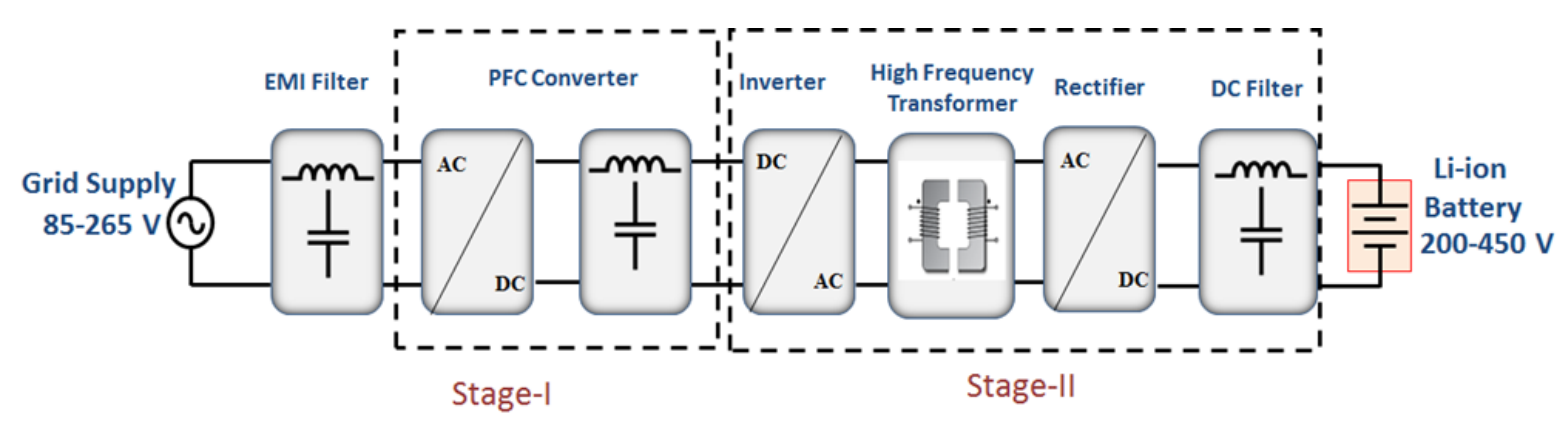

Fig. 10. Block diagram of on board charger stages 
In the block diagram of Fig. 3, Stages II\&I are the same for both conductive and inductive power chargers [49]. Stage II in the wireless charger is separated with a magnetic coil of specified air gap length and the corresponding compensations on primary and on secondary. The EMI filter shown in the charger is required to filter the common mode and differential mode noise, surge protector and harmonics suppressor. There are many challenges in using the resonant converters for the charging application to have a wide output voltage [51] - [52]. The overview of the paper is to design a charger with minimized size and weight, universal output voltage and faster rate of charge. An EV charger must ensure that the utility current is drawn with low distortion to minimize the power quality impact and at high power factor to maximize the real power available from a utility outlet. IEEE-1547, SAE-J2894, IEC1000-3-2, ECR-10(Rev.4), CISPR-25, and the U.S. National Electric Code (NEC) 690 standards limit the allowable harmonic and dc current injection into the grid, and EV chargers are usually designed to comply [53]-[59]. The overview of the stages is shown in Fig.4.

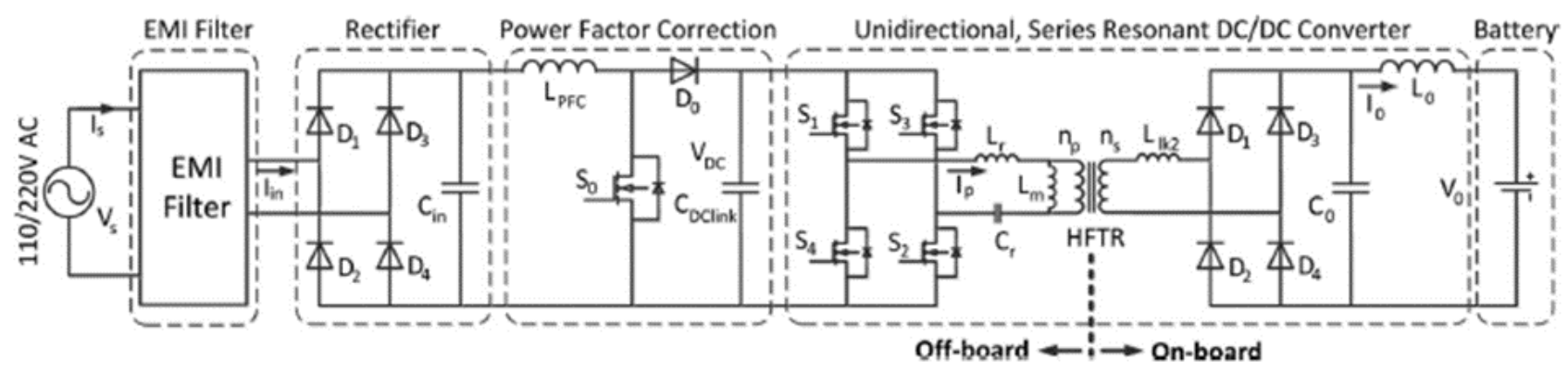

Fig.11. Overview of an isolated onboard charger [61]

The two-stage topology as shown in Fig.11 consists of only AC-DC power conversion. To avoid the additional DC-DC converter for the low voltage (LV) modules the integrated on-board with AC-DC for main Battery and DC-DC converter for auxiliary loads operated with LV supply (12/24 V) as proposed in [62]-[63].

\section{v. CONCLUSIONS}

This paper discusses some of the topologies in the area of energy storage for electric vehicles. Various charging technology for onboard electric vehicle battery was discussed. Some possible state of the art technologies have been presented in this paper. Using solar grid tied inverter/chargers can be used for charging at residential locations converting residential houses into a charging station. MMC technology is an attractive solution for onboard energy storage and $\mathrm{AC}$ onboard charging directly from the grid is a convenient way of charging directly from the AC supply. The various standards for charging are also presented for the discussed topologies.

\section{REFERENCES}

[1] J. Deng, S. Li, S. Hu, C. C. Mi and R. Ma. "Design methodology of LLC resonant converters for electric vehicle battery chargers," IEEE Transactions on Vehicular Technology, vol. 63, no. 4, pp. 1581-1592, May. 2014.

[2] D. S. Gautam, F. Musavi, W. Eberle and W. G. Dunford. "A zero-voltage switching full-bridge dc-dc converter with capacitive output filter for plug-in hybrid electric vehicle battery charging," IEEE Transactions on Power Electronics, vol. 28, , no. 12, pp. 5728-5735, Dec. 2013.

[3] D. S. Gautam, F. Musavi, M. Edington, W. Eberle and W. G. Dunford. "An automotive onboard 3.3- kw battery charger for PHEV application," IEEE Transactions on Vehicular Technology, vol. 61 , no. 8, pp. 3466-3474, Oct. 2012.

[4] Y. Du, X. Zhou, S. Bai, S. Lukic and A. Huang. "Review of non-isolated bi-directional dc-dc converters for plugin hybrid electric vehicle charge station application at municipal parking decks," Proc. Of Twenty-Fifth Annual IEEE Applied Power Electronics Conference and Exposition (APEC), 2010, pp.1145-1151. 
[5] Y. Du, S. Lukic, B. Jacobson and A. Huang. "Review of high power isolated bi-directional dcdc converters for phev/ev dc charging infrastructure," Proc. of IEEE Energy Conversion Congress and Exposition, 2011, pp. 553-560. .

[6] SAE Electric Vehicle and Plug in Hybrid Electric Vehicle Conductive Charge Coupler, SAE International Surface Vehicle Recommended Practice, J1772, Oct. 2012.

[7] S. Li and C. C. Mi. "Wireless power transfer for electric vehicle applications," IEEE Journal of Emerging and Selected Topics in Power Electronics, vol. 3, no. 1, pp. 4-17, March 2015.

[8] G. A. Covic and J. T. Boys. "Inductive Power Transfer," Proc. of the IEEE, vol. 101, no. 6, 2013, pp. 1276-1289. .

[9] D. Rozario, V. K. Pathipati, A. Ram, N. A. Azeez and S. S. Williamson. "Modified resonant converters for contactless capacitive power transfer systems used in EV charging applications," Proc. of 42nd Annual Conference of the IEEE Industrial Electronics Society, Florence, 2016, pp. 4510-4517.

[10] F. Z. Peng. "Z-source inverter," IEEE Transactions on Industrial Electronics, vol. 39, no. 2, pp. 504-510, 2003.

[11] G. Carli and S. S. Williamson. "Technical considerations on power conversion for electric and plug-in hybrid electric vehicle battery charging in photovoltaic installations," IEEE Transactions on Power Electronics, vol. 28, no. 12, pp. 5784- 5792, 2013.

[12] S. A. Singh, G. Carli, N. A. Azeez and S. S. Williamson. "A modified Z-source converter based single phase PV/grid inter-connected DC charging converter for future transportation electrification," Proc. of IEEE Energy Conversion Congress and Exposition (ECCE), Milwaukee, WI, 2016, pp. 1-6.

[13] W. E. Rippel and A. G. Cocconi. "Integrated motor drive and recharge system," U.S. Patent 5099186, Mar. 1992.
[14] G. Cocconi. "Combined motor drive and battery charger system," U.S. Patent 5341 075, Aug. 1994.

[15] S. Haghbin, S. Lundmark, M. Alakula and O. Carlson. "Grid-connected integrated battery chargers in vehicle applications: Review and new solution," IEEE Transactions on Industrial Electronics, vol. 60, no. 2, pp. 459-473, Feb. 2013.

[16] M. Yilmaz and P. T. Krein. "Review of battery charger topologies, charging power levels, and infrastructure for plug-in electric and hybrid vehicles," IEEE Transactions on Power Electronics., vol. 28, no. 5, pp. 2151-2169, May 2013.

[17] AC Propulsion EV Drive System Specifications, 2008. AC Propulsion Inc. technical note; [Online]. Available http://www.acpropulsion.com.html.

[18] S. Lacroix, E. Laboure and M. Hilairet. "An integrated fast battery charger for electric vehicle," Proc. IEEE Vehicle Power and Propulsion Conference, Lille, France, 2010, pp. 1-6.

[19] L. De-Sousa and B. Bouchez. "Combined electric device for powering and charging," Int. Patent WO 2010/057892 A1, 2010.

[20] G. Pellegrino, E. Armando and P.Guglielmi. "An integral battery charger with power factor correction for electric scooter," IEEE Transactions on Power Electronics, vol. 25, no. 3, pp. 751-759, Mar. 2010.

[21] F. Lacressonniere and B. Cassoret. "Converter used as a battery charger and a motor speed controller in an industrial truck," Proc. European Power Electronic conference, 2005, pp. 1-7.

[22] S. Haghbin, S. Lundmark, M. Alakula and O. Carlson. "An isolated high-power integrated charger in electrified vehicle applications," IEEE Transactions on Vehicle. Technology, vol. 60, no. 9, pp. 4115-4126, Nov. 2011.

[23] S. Haghbin, K. Khan, S. Zhao, M. Alakula, S. Lundmark and O. Carlson. "An integrated 20-kW motor drive and isolated battery charger for plug- 
in vehicles," IEEE Transactions on Power Electronics, vol. 28, no. 8, pp. 4013-4029, Aug. 2013.

[24] K. Khan, S. Haghbin, M. Leksell and O.Wallmark. "Design and performance analysis of a permanent-magnet assisted synchronous reluctance machine for an integrated charger application," Proc. Int. Conf. Elect.Mach., 2010, pp. 1-6.

[25] J. Liang, W. Li, Z. Song and Y. Shi. "An integrated battery charger base on split-winding switched reluctance motor drive," Proc. IEEE Transportation Electrification Conference and Expo, Asia-Pacific (ITEC Asia-Pacific), Busan, 2016, pp. 106-111.

[26] I. Subotic, N. Bodo and E. Levi, "Single-phase on-board integrated battery chargers for EVs based on multiphase machines," IEEE Trans. Power Electron., vol. 31, no. 9, pp. 6511-6523, Sept. 2016.

[27] M. S. Diab, A. A. Elserougi, A. S. Abdel-Khalik, A. M. Massoud and S. Ahmed. "A nine-switchconverter-based integrated motor drive and battery charger system for EVs using symmetrical six-phase machines," IEEE Transactions on Industrial Electronics, vol. 63, no. 9, pp. 5326-5335, Sept. 2016.

[28] I. Subotic, M. Jones and E. Levi. "A fast onboard integrated battery charger for four-motor EVs," Proc. IEEE Conference on Electrical Machines (ICEM), Berlin, 2014, pp. 2066-2072.

[29] H. C. Chang and C. M. Liaw. "Development of a compact switched-reluctance motor drive for EV propulsion With voltage-boosting and PFC charging capabilities," IEEE Transactions on Vehicle Technology, vol. 58, no. 7, pp. 31983215, Sept. 2009.

[30] C. Gan, J. Wu, Y. Hu, S. Yang, W. Caoand J. M. Guerrero. "New integrated multilevel converter for switched reluctance motor drives in plug-in hybrid electric vehicles with flexible energy conversion," IEEE Transactions on Power Electronics, vol. 32, no.99, pp.3754-3766.
[31] M. Quraan, T. Yeo and P. Tricoli. "Design and control of modular multilevel converters for battery electric vehicles," IEEE Transactions on Power Electronics, vol. 31, no. 1, pp. 507-517, Jan. 2016.

[32] F. Helling, J. Glück, A. Singer and T. Weyh. "Modular multilevel battery (M2B) for electric vehicles," Proc. European Conference on Power Electronics and Applications (EPE'16 ECCE Europe), Karlsruhe, 2016, pp. 1-9.

[33] N. Li, F. Gao, T. Yang, L. Zhang, Q. Zhang and G. Ding. "An integrated electric vehicle power conversion system using modular multilevel converter,' Proc. IEEE Energy Conversion Congress and Exposition (ECCE), Montreal, QC, 2015, pp. 5044-5051.

[34] M. Tsirinomeny and A. Rufer. "Configurable modular multilevel converter (CMMC) for flexible EV," Proc. of European Conference on Power Electronics and Applications (EPE'15 ECCEEurope), Geneva, 2015, pp. 1-10.

[35] S. Rohner, S. Bernet, M. Hiller and R. Sommer. "Modulation, losses, and semiconductor requirements of modular multilevel converters," IEEE Transactions on Industrial Electronics, vol. 57, no. 8, pp. 2633-2642, Aug. 2010.

[36] S. Debnath, J. Qin, B. Bahrani, M. Saeedifard and P. Barbosa. "Operation, control, and applications of the modular multilevel converter: A review," IEEE Transactions on Power Electronics, vol. 30, no. 1, pp. 37-53, Jan. 2015.

[37] Morrow, D. Karner and J. Francfort. "Plug-in hybrid electric vehicle charging infrastructure review," U.S. Dept. Energy-Vehicle Technologies Program, Washington, DC, INLEXT-08-15058, 2008.

[38] M. Yilmaz and P. T. Krein. "Review of battery charger topologies, charging power levels, and infrastructure for plug-in electric and hybrid vehicles," IEEE Transactions on Power Electronics, vol. 28, no. 5, pp. 2151-2169, May 2013.

[39] M. A. Fasugba and P. T. Krein, "Gaining vehicleto-grid benefits with unidirectional electric and 
plug-in hybrid vehicle chargers," Proc. IEEE Veh. Power and Propulsion Conf., Sep. 2011, pp. 1-6.

[40] X. Zhou, S. Lukic, S. Bhattacharya and A. Huang. "Design and control of grid-connected converter in Bi-directional battery charger for plugin hybrid electric vehicle application," Proc. IEEE Vehicle Power and Propulsion Conf., Sep. 2009, pp. 1716-1721.

[41] Y. Lee, A. Khaligh and A. Emadi "Advanced integrated bi-directional $A C / D C$ and $D C / D C$ converter for plug-in hybrid electric vehicles," IEEE Transactions on Vehicle Technology, vol. 58, no. 3, pp. 3970-3980, Oct. 2009.

[42] K. Keun-Wan, K. Dong-Hee, W. Dong-Gyun and L. Byoung-Kuk. "Topology comparison for 6.6 kW On board charger: Performance, efficiency, and selection guideline," Proc. IEEE VPPC, 2012, pp. 1520-1524.

[43] B. Singh, B. N. Singh, A. Chandra, K. AlHaddad, A. Pandey and D. P. Kothari. "A review of single-phase improved power quality AC-DC converters," IEEE Transactions on Industrial Electronics, vol. 50, no. 5, pp. 962-981, Oct. 2003.

[44] D. Xu, J. Zhang, W. Chen, J. Lin and F. C. Lee. "Evaluation of output filter capacitor current ripples in single phase PFC converters," Proc. PCC, Osaka, Japan, 2002, vol. 3, pp. 12261231.

[45] L. Petersen and M. Andersen. "Two-stage power factor corrected power supplies: The low component-stress approach," Proc. IEEE APEC, vol. 2, 2002, pp. 1195-1201.

[46] B. Lu, R. Brown and M. Soldano. "Bridgeless PFC implementation using one cycle control technique," Proc. IEEE Appl. Power Electron. Conf. Expo., vol. 2, 2005, pp. 812-817.

[47] C. Petrea and M. Lucanu. "Bridgeless power factor correction converter working at high load variations," in Proc. ISSCS, vol. 2, 2007,pp. 1-4.

[48] M. Kwon and S. Choi. "An electrolytic capacitorless bidirectional EV charger for V2G and V2H applications," in IEEE Transactions on
Power Electronics, vol. 32, no. 9, pp. 6792-6799, Sept. 2017.

[49] T. Nussbaumer, M. Baumann and J. W. Kolar. "Comparative evaluation of modulation methods of a three-phase buck + boost PWM rectifier. Part II: Experimental verification," Power Electronics, IET, vol. 1, no. 2, pp. 268-274, Jun. 2008.

[50] T. Nussbaumer and J. W. Kolar. "Comparison of 3-phase wide output voltage range PWM rectifiers," IEEE Transactions on Industrial Electronics, vol. 54, no. 6, pp. 3422-3425, Dec. 2007.

[51] M. Pahlevaninezhad, P. Das, J. Drobnik, P. K. Jain and A. Bakhshai. "A ZVS interleaved boost $A C / D C$ converter used in plug-in electric vehicles, " IEEE Transactions on Power Electronics, vol. 27, no. 8, pp. 3513-3529,Aug. 2012.

[52] A. Khaligh and S. Dusmez. "Comprehensive topological analysis of conductive and inductive charging solutions for plug-in electric vehicles," IEEE Transactions on Vehicle Technology, vol. 61, no. 8, pp. 3475-3489, Oct. 2012.

[53] F. Musavi, M. Craciun, D. S. Gautam,W. Eberle andW. G. Dunford. "An LLC resonant DC-DC converter for wide output voltage range battery charging applications," IEEE Transactions on Power Electronics, vol. 28, no. 12, pp. 54375445, Dec. 2013.

[54] F. Musavi, M. Craciun, M. Edington, W. Eberle and W. G. Dunford. "Practical design considerations for a LLC multi-resonant DC-DC converter in battery charging applications," Proc. 27th Annual IEEE APEC Expo., 2012, pp. 25962602.

[55] IEEE Recommended Practices and Requirements for Harmonic Control in Electrical Power Systems, IEEE Std. 519-1992, 1992.

[56] Compliance Testing to the IEC 1000-3-2 (EN 61000-3-2) and IEC 1000-3-3 (EN 61000-3-3) Standards, Agilent Technology.

[57] T. S. Key and J.-S. Lai. "IEEE and international harmonic standards impact on power electronic 
equipment design," in Proc. IECON, vol. 2, 1997,pp. 430-436.

[58] Fairchild document Design Consideration for Battery Charger Using Green Mode Fairchild Power Switch. (2007) [Online]. Available: www.fairchildsemi.com.

[59] C. H. Lin, C. Y. Hsieh and K. H. Chen. "A Li-ion battery charger with smooth control circuit and built-in resistance compensator for achieving stable and fast charging," IEEE Transactions on Circuits Systems I, Reg. Papers, vol. 57, no. 2, pp. 506-517, Feb. 2010.

[60] S.- H. Yang, J. Liu, Y. H. Wu, D. S. Wang and C. C. Wang. "A high voltage battery charger with smooth charge mode transition in BCD process," Proc. IEEE Int. Symp. Circuits Syst., May 2011, pp. 813-816.
[61] M. Yilmaz and P. T. Krein. "Review of battery charger topologies, charging power levels, and infrastructure for plug-in electric and hybrid vehicles," IEEE Trans. Power Electron., vol. 28, no. 5, pp. 2151-2169, May 2013.

[62] D. H. Kim, M. J. Kim and B. K. Lee, "An integrated battery charger with high power density and efficiency for electric vehicles," IEEE Transactions on Power Electronics, vol. 32, no. 6, pp. 4553-4565, June 2017.

[63] R. Hou and A. Emadi. "A primary full-integrated active filter auxiliary power module in electrified vehicles with single-phase onboard chargers," IEEE Transactions on Power Electronics, vol. 32, no. 11, pp. 8393-8405, Nov. 2017. 